\title{
Determination of Potential Runoff Coefficient Using GIS and Remote Sensing
}

\author{
Ragab Khalil1,2 \\ ${ }^{1}$ Civil Engineering Department, Faculty of Engineering, Assiut University, Assiut, Egypt \\ ${ }^{2}$ Landscape Architecture Department, Faculty of Environmental Design, King AbdulAziz University (KAU), Jeddah, KSA \\ Email: khalilragab@yahoo.com
}

How to cite this paper: Khalil, R. (2017) Determination of Potential Runoff Coefficient Using GIS and Remote Sensing. Journal of Geographic Information System, 9, 752-762. https://doi.org/10.4236/jgis.2017.96046

Received: December 4, 2017

Accepted: December 25, 2017

Published: December 28, 2017

Copyright (c) 2017 by author and Scientific Research Publishing Inc. This work is licensed under the Creative Commons Attribution International License (CC BY 4.0).

http://creativecommons.org/licenses/by/4.0/

\begin{abstract}
Flash floods in arid environments are a major hazard feature to human and to the infrastructure. Shortage of accurate environmental data is main reason for inaccurate prediction of flash flooding characteristics. The curve number $(\mathrm{CN})$ is a hydrologic number used to describe the storm water runoff potential for drainage area. This study introduces an approach to determine runoff coefficient in Jeddah, Saudi Arabia using remote sensing and GIS. Remote sensing and geographic information system techniques were used to obtain and prepare input data for hydrologic model. The land cover map was derived using maximum likelihood classification of a SPOT image. The soil properties (texture and permeability) were derived using the soil maps published my ministry of water and agriculture in Saudi Arabia. These soil parameters were used to classify the soil map into hydrological soil groups (HSG). Using the derived information within the hydrological modelling system, the runoff depth was predicted for an assumed severe storm scenario. The advantages of the proposed approach are simplicity, less input data, one software used for all steps, and its ability to be applied for any site. The results show that the runoff depth is directly proportional to runoff coefficient and the total volume of runoff is more than 136 million cubic meters for a rainfall of $103.6 \mathrm{~mm}$.
\end{abstract}

\section{Keywords}

Potential Runoff Coefficient (PRC), GIS, Remote Sensing, Hydrological Soil Group (HSG), Digital Elevation Model (DEM), Land Use

\section{Introduction}

In arid zones, there is a shortage of data needed for hydrological processes as mentioned by [1]. In these zones flash flooding happened suddenly and affects 
both human and infrastructure. The effective way to reduce the damages due to flood is to predict the critical sites affected by flash flood for management planes. The part of rainfall that turns to runoff due to land use and soil hydrological parameters is defined as runoff coefficient [2]. It may also be defined as the ratio between the runoff depth and the rainfall depth [3]. The reasonable calculation of runoff from rainfall is the key for flood estimation [4] [5]. Defining rainfall-runoff relationship leads to calculate flood properties such as runoff depth, peak discharge, runoff speed, and runoff volume. Flood properties derivation is important for planners and decision makers to avoid flood hazard effects. When flood discharge data records are missed, there are many approaches to estimate runoff depth and volume based on soil and surface properties of catchment area. These approaches may be summarized into three groups, simple, moderate and complex models as stated by [4]. The curve number $(\mathrm{CN})$ is one of the moderate complicity models and it is widely used for flood estimation. The $\mathrm{CN}$ model was developed by United States Department of Agriculture (USDA), National Resources Conservation Service (NRSC) in 1969 [6]. It is an empirical model with clearly stated assumptions and few data requirements [7]. $\mathrm{CN}$ is stable conceptual method for predicting of direct runoff depth using storm rainfall intensity, land use and soil hydrological properties of a catchment.

Remote sensing imageries considered a major source of spatial data especially for wide area or when the ground surveys are not available. They can be used to generate land use, soil and geological maps needed for flood estimation. Geographic Information System (GIS) is a powerful tool in hydrological modelling because of its capability to handle large amount of spatial and attribute data. Delineation of hydrological catchments, map overlay and analysis, which are basics of GIS software, help for derivation and aggregation of hydrologic parameters from the input data like DEM, soil map, land use map, and rainfall data. Remote sensing (RS) images and Geographic Information System (GIS) techniques have been used in flood hazard studies by many researchers, e.g. [8]-[18].

The main objective of this research article is determining the potential runoff coefficient for Jeddah, Saudi Arabia by applying CN model and using remote sensing and GIS techniques.

\section{Study Area}

Jeddah is the second main city in Saudi Arabia. It is at the middle of east coast of the Red Sea and represents the important commercial port. Its population exceeds 3.4 million people according to (Central Department of Statistics \& Information 2010) with $3.5 \%$ annual rate of growth make its population exceeds 4.2 million people. Its weather condition is classified as hot. A rainfall intensity of 80 and $124 \mathrm{~mm}$ /day hit Jeddah in November 2009 and January 2011, respectively as mentioned by [19]. Reference [20] mentioned that these occasional floods were examples of flash flood striking which characterized by short durations and destructive results. The watershed that affected the city is located between $\left(21^{\circ} 15^{\prime} \mathrm{N}\right.$, $\left.21^{\circ} 50^{\prime} \mathrm{N}\right)$ and $\left(39^{\circ} 0^{\prime} \mathrm{E}, 39^{\circ} 35^{\prime} \mathrm{E}\right)$ as shown in (Figure 1). 


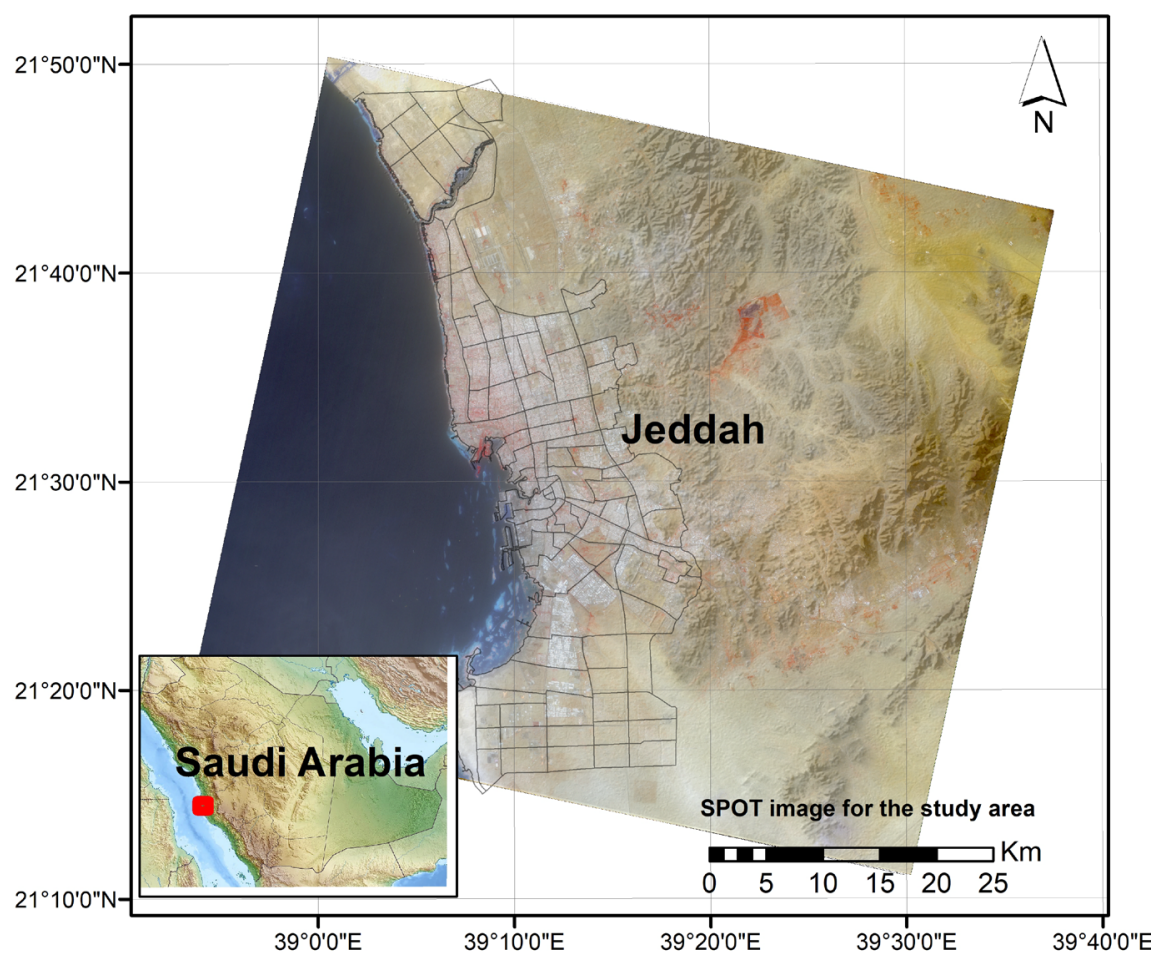

Figure 1. Location of the study area.

\section{Data and Methodology}

The available rainfall data for Jeddah are from two rain gauge stations, J134 which operated by the Ministry of Water and Electricity (MOWE) and 41024 (airport station) which operated by Presidency of Meteorology and Environment (JMPE) [21]. The data represent the recorded observation for a period of 42 years extending from January 1971 to December 2012; no data were available for the most recent years. The maximum annual daily rainfall for the two stations is shown in (Figure 2). High resolution satellite image SPOT5 (2.5 m multispectral) was obtained from King Abdulaziz City for Science and Technology (KACST) and used generate land use map. Topography data was obtained using Shuttle Radar Topography Mission (SRTM) digital elevation model (DEM) and used to extract slope data and stream network. Soil data were obtained using Saudi general soil map, ministry of agricultural and water 1986.

The methodology used to determine the potential runoff coefficient for the study area using remote sensing and GIS is shown in the flow chart in (Figure 3). It starts with scanning and Georeferencing the soil maps using ArcMap 10.4, the soil polygons were digitized, and each soil type was assigned to a Hydrological Soil Group (HSG) according to [22]. Image classification tool in ArcMap 10.4 was used to classify and convert the SPOT image to land use thematic map by applying the supervised classification technique. The DEM was used to generate slope map using surface analysis tool, and to generate stream network and basin parameters using HEC-GeoHMS. The runoff curve number lookup table was build according to the land use map and [22]. All data were then overlaid in 


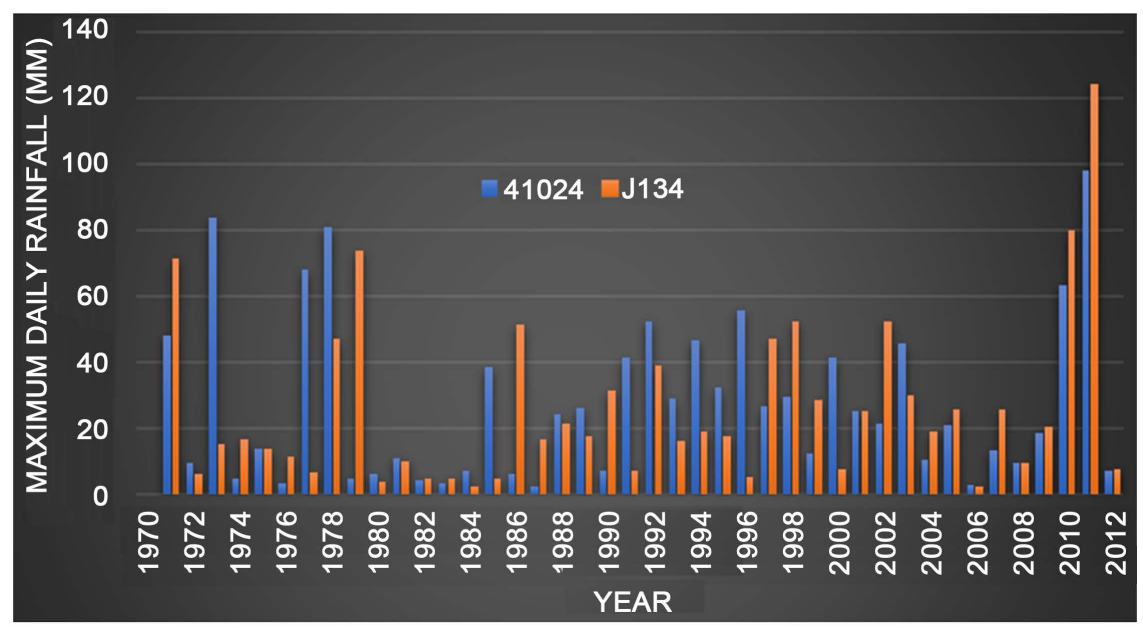

Figure 2. Rainfall data for the two rain gauges.

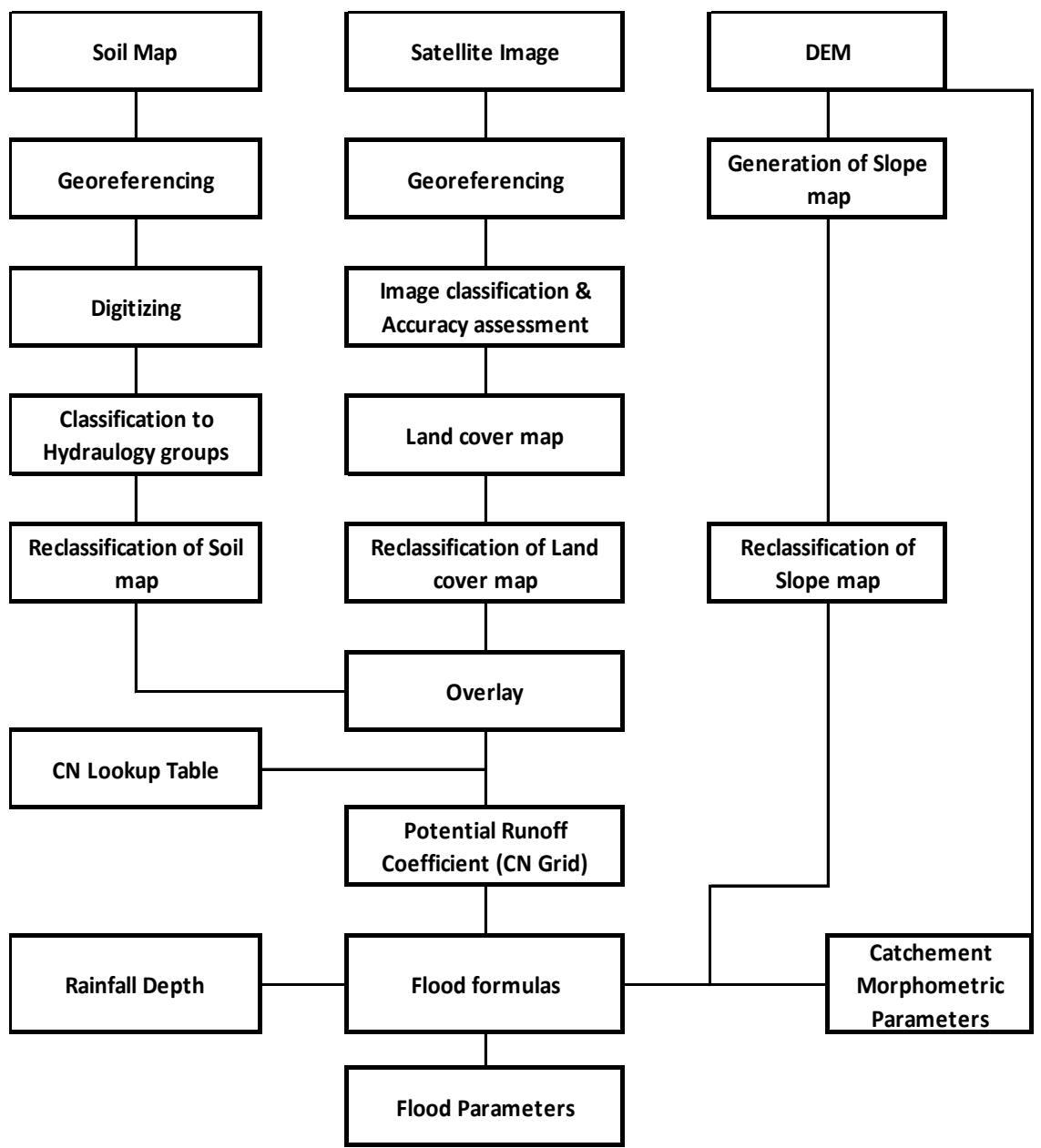

Figure 3. Methodology flowchart.

ArcGIS environment to generate the runoff coefficient. Lastly, the flood formulas were applied to calculate the flood parameters using field calculator in ArcMap 10.4. 


\subsection{Land Use Analysis}

SPOT image $(2.5 \mathrm{~m})$ for the year 2010 was obtained from the King Abdul-Aziz City for Science and Technology (KACST). Supervised classification was performed to the image using spectral signatures collected from training samples (polygons that represent distinct sample areas of the different land cover types to be classified). After preparing the signature file, Maximum likelihood classifier then attached labels to all the image pixels according to the trained parameters to generate land cover map. The land cover map was classified into six main classes: water, vegetation, rocks, bare soil, and build up area as shown in (Figure $4)$.

\subsection{Soil Type Analysis}

The general soil map of Saudi Arabia was the source for soil data used in this study. The general soil map was scanned and georeferenced then different types of soil were digitalized in ArcMap 10.4. Each type of soil was assigned to the proper hydrological soil group that developed by US Soil Conservation Service (SCS). According to SCS, all the soil, based on their permeability and infiltration are divided to 4 groups A, B, C and D. Hydrological Soil Group of A has the lowest runoff potential while group $\mathrm{D}$ has the highest. The soil map was then classified into Hydrological Soil Groups (HSGs) as shown in Figure 5.

\subsection{Slope Analysis}

The runoff velocity and soil erosion are in direct proportional to the degree of

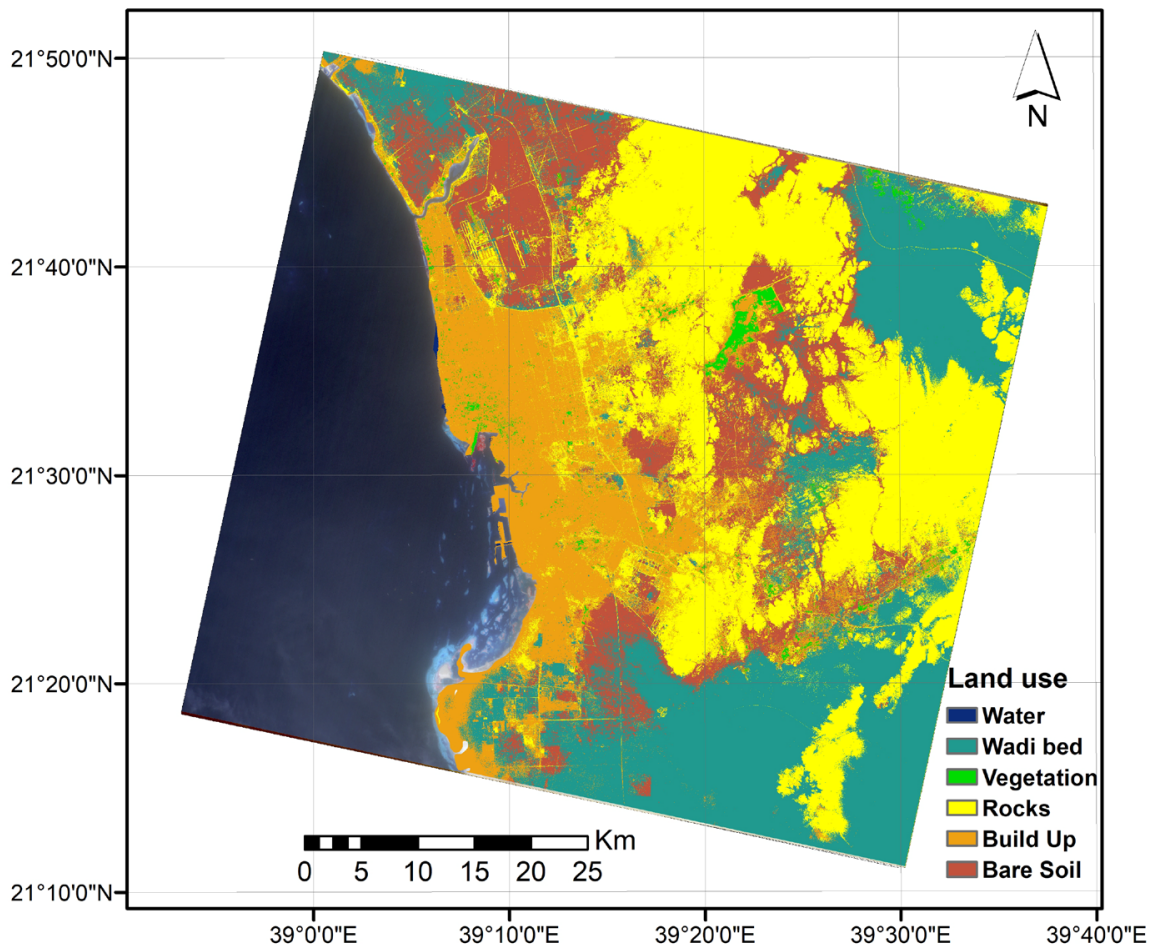

Figure 4. Land use map. 


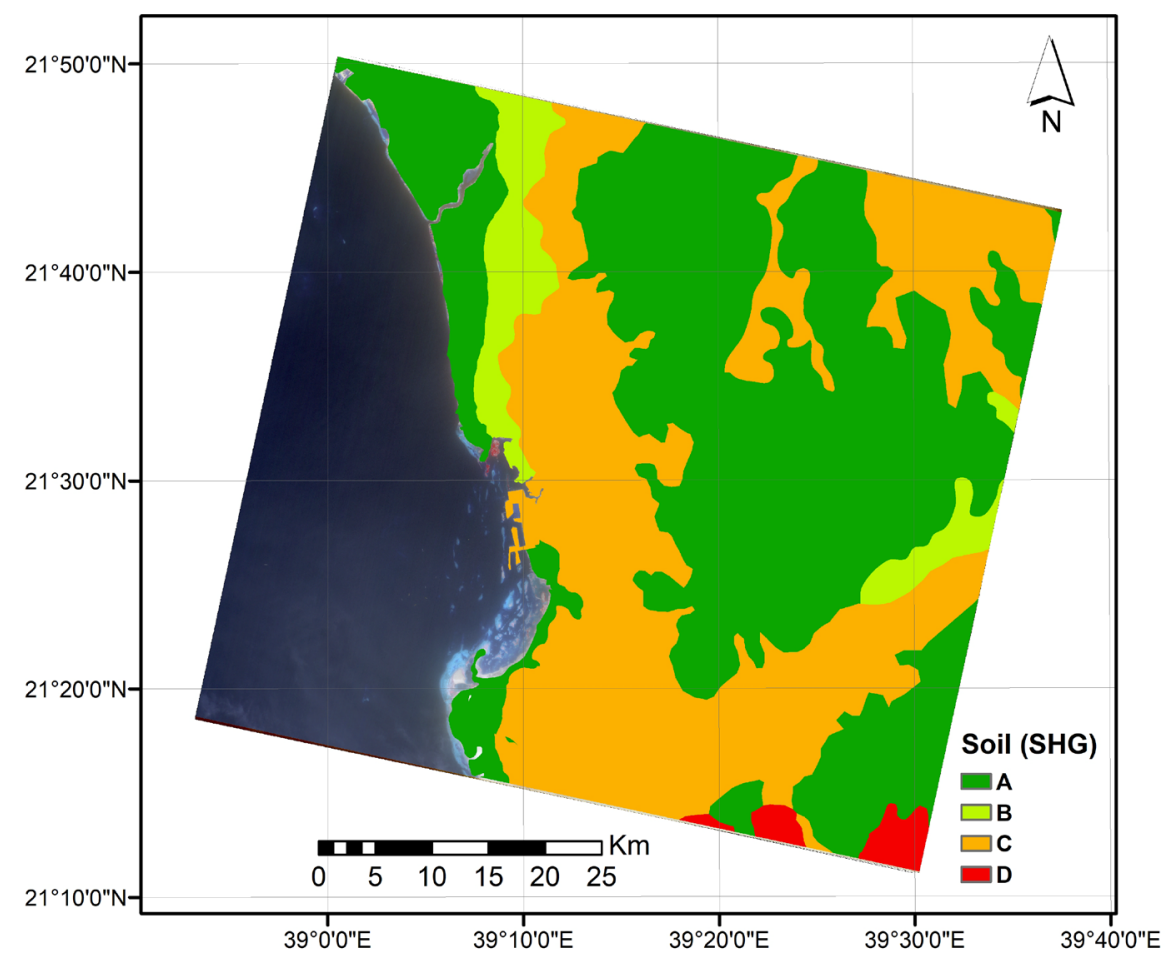

Figure 5. Soil hydrological groups map.

slope. Digital Elevation Model (DEM) obtained from SRTM was used to generate slope map as shown in Figure 6. The DEM analyzed to remove sinks and flat areas to maintain continuity of flow to the catchment outlets. The GIS used for DEM preparation by filling the sink areas.

\section{Potential Runoff Coefficient}

As flash flood in Jeddah occurred with rainfall didn't exceed $80 \mathrm{~mm}$ and rainstorm duration didn't exceed 3 hours, it is important to estimate the expected flood discharges of return periods reliably for protection and future developments [23]. The rainfall data was used to predict the rainfall depth at different return periods. Among many of the probability density functions, numerous studies recommended the Gumbel or Extreme Value Type I (EV1) function as it demonstrated the best fit in most cases and providing the best prediction of rainfall depth. The estimated rainfall depth for different return periods for the two rain gauge stations for JPME (41024) and J134 are shown in Table 1.

The flood hazard parameters such as watershed storage, runoff depth, and volume of runoff were calculated. The $\mathrm{CN}$ method Equation (1) was used for runoff depth calculation [22].

$$
\begin{gathered}
Q=2(P-0.2 S) /(P+0.8 S) \\
S=25400 / C N-254
\end{gathered}
$$

where

$Q$ : the direct runoff depth $(\mathrm{mm})$, 


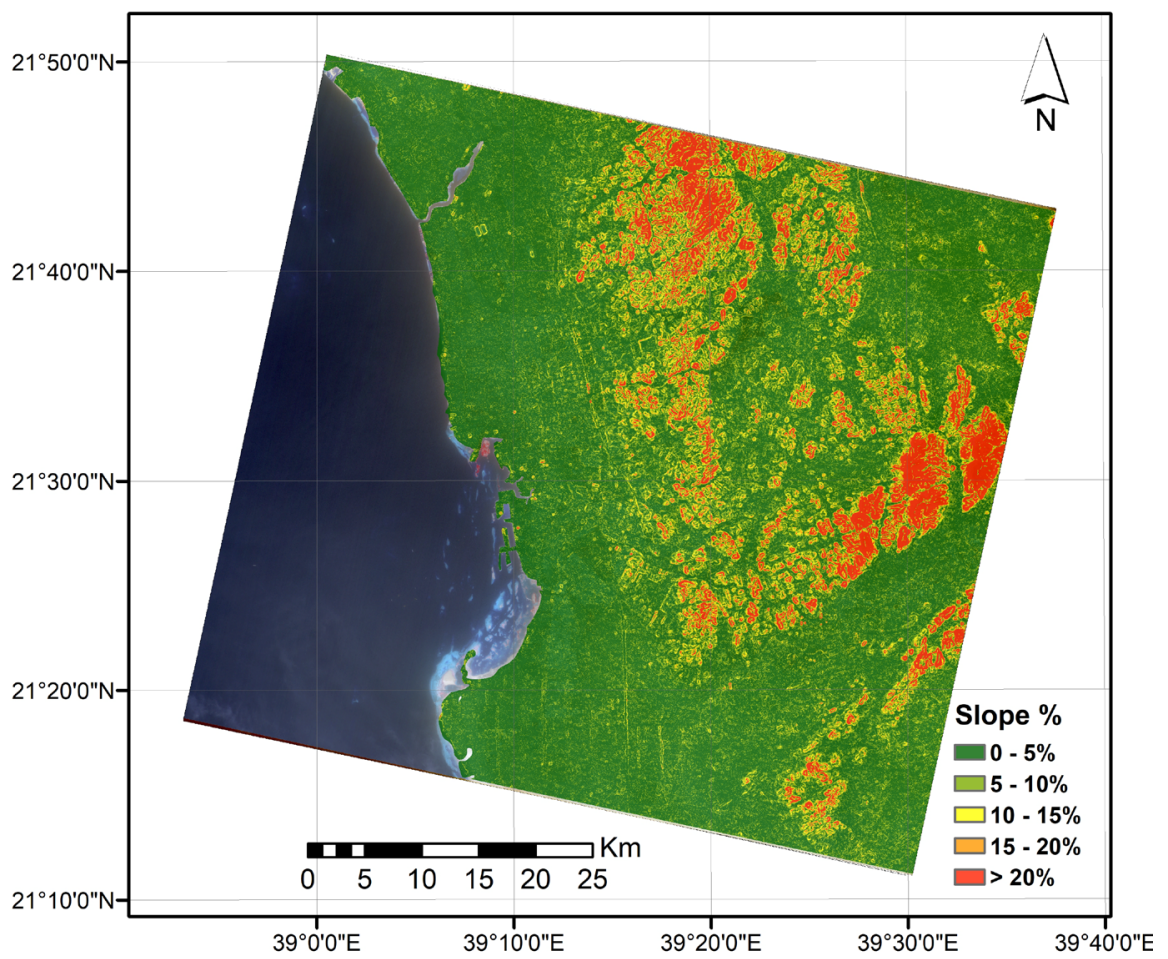

Figure 6. Slope map.

Table 1. Estimated daily rainfall $(\mathrm{mm})$ for different return periods.

\begin{tabular}{ccccccc}
\hline Return period (years) & 5 & 10 & 20 & 25 & 50 & 100 \\
\hline JMPE & 45.5 & 60.0 & 74.0 & 78.4 & 92.0 & 105.5 \\
J134 & 44.5 & 59.5 & 73.8 & 78.4 & 92.4 & 106.3 \\
\hline
\end{tabular}

$P$. depth of precipitation for a specific return period $(\mathrm{mm})$,

$S$ : the watershed storage ( $\mathrm{mm}$ ), and can be calculated using Equation (2),

$C N$ : the curve number.

The volume of the runoff was calculated for subbasins to show the local effect of runoff and was also calculated for the major basins to show the total volume of runoff flood. The volume of the runoff can be calculated using Equation (3)

$$
V_{Q}=Q \cdot A
$$

where

$V_{Q}$ : Volume of runoff $\left(\mathrm{m}^{3}\right)$,

$Q$ : Depth of runoff $(\mathrm{m})$,

$A$ : Basin area $\left(\mathrm{m}^{2}\right)$.

\section{Results}

The flood characteristics were calculated using the rainfall depth (P) equals 106.3 $\mathrm{mm}$ for a return period of 100 years as shown in Table 1 . These characteristics include area, longest flow length and the runoff volume of the main basins in Jeddah watershed area as shown in Table 2. The results show that there are 7 major and 5 minor basins in Jeddah as shown in (Figure 7). The areas of the 


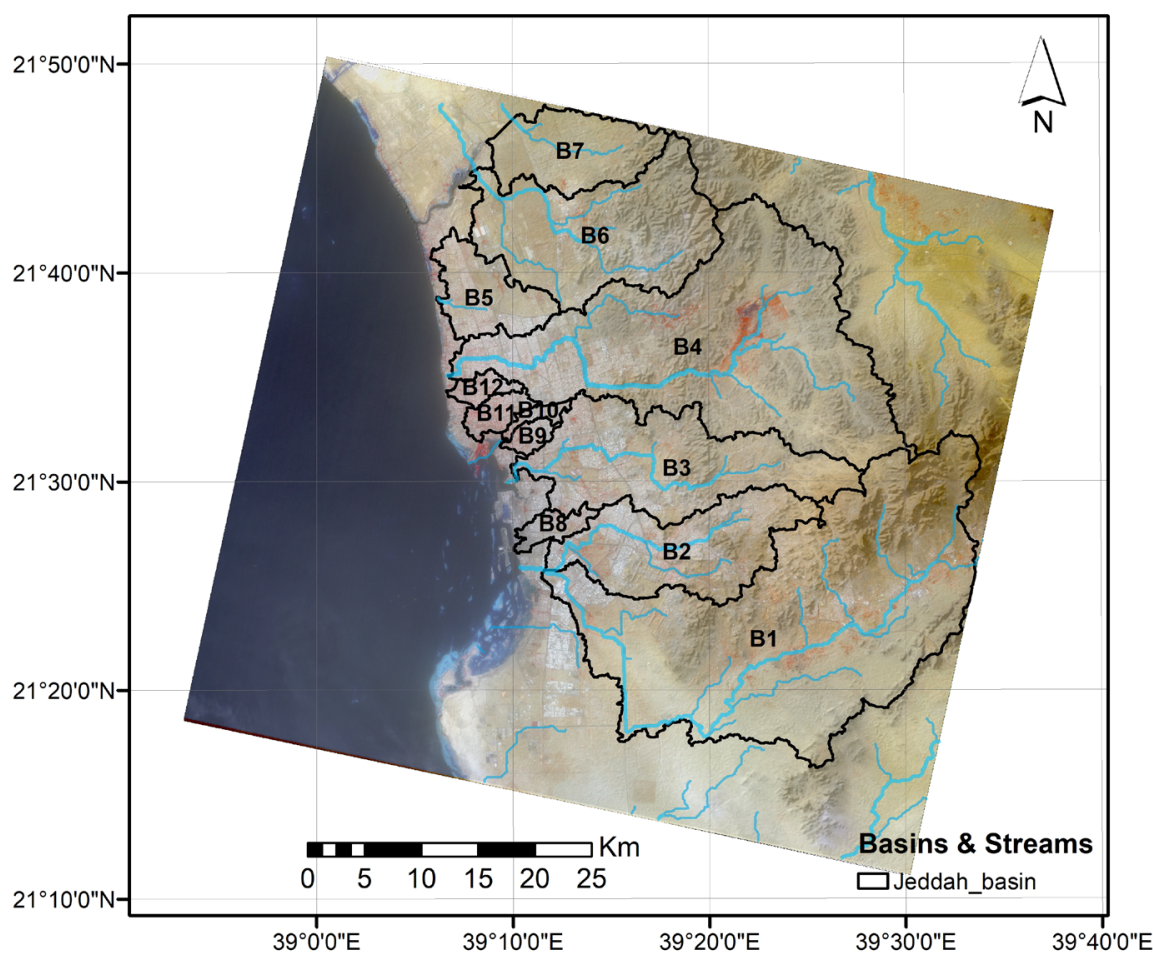

Figure 7. Basins and main streams.

Table 2. Morphometric and flood parameters of basins.

\begin{tabular}{ccccccc}
\hline Basin & Area $\left(\mathrm{km}^{2}\right)$ & $\begin{array}{c}\text { Longest } \\
\text { flow path }(\mathrm{m})\end{array}$ & CN & Slope \% & $\begin{array}{c}\text { Runoff depth } \\
(\mathrm{mm})\end{array}$ & $\begin{array}{c}\text { Runoff volume } \\
\left(\text { million } \mathrm{m}^{3}\right)\end{array}$ \\
\hline B1 & 555.47 & $77,410.48$ & 88.8 & 5.63 & 75.8 & 42.553 \\
B2 & 143.28 & $32,825.69$ & 91.4 & 5.25 & 82.5 & 11.452 \\
B3 & 192.27 & $42,556.96$ & 90.3 & 4.60 & 80.3 & 14.382 \\
B4 & 448.60 & $62,297.97$ & 90.7 & 5.83 & 80.8 & 36.001 \\
B5 & 59.04 & $12,715.07$ & 88.7 & 1.37 & 75.5 & 4.501 \\
B6 & 201.10 & $35,140.56$ & 90.5 & 7.62 & 80.4 & 16.458 \\
B7 & 84.79 & $19,882.92$ & 87.5 & 3.22 & 72.7 & 6.224 \\
B8 & 14.61 & $10,231.69$ & 93.6 & 2.11 & 88.1 & 1.287 \\
B9 & 9.40 & 7486.95 & 93.6 & 2.14 & 88.0 & 0.827 \\
B10 & 6.98 & 9332.22 & 93.5 & 2.12 & 87.8 & 0.613 \\
B11 & 15.47 & 9040.97 & 91.2 & 1.64 & 81.8 & 1.265 \\
B12 & 11.21 & 8113.69 & 91.5 & 1.43 & 82.3 & 0.923 \\
& & & & & & \\
\hline
\end{tabular}

major basins range from 59.04 to 555.5 square kilometers, and their longest flow paths range from 12.7 to 77.4 kilometers, while the areas of the minor basins range from 6.9 to 15.5 square kilometers, and their longest flow paths range from 7.48 to 10.23 kilometers. The total runoff volume was calculated and found to be more than 136 million cubic meters. 
Refereeing to (Table 2), one can notice that the runoff depth $(\mathrm{Q})$ is directly proportional to the curve number and inversely proportional to slope and the curve number has the great effect on it.

The proposed approach of using remote sensing and GIS applying the $\mathrm{CN}$ method for runoff coeffecient estimation has many advantages over other approaches. Firstly, it uses one software to perform all procedure steps. Secondly, only satellite image, soil maps and DEM are needed to calculate the runoff parameters. Thirdly, all needed calculations are done within the GIS environment using field calculation. Fourthly, it can be modeled using model builder so, runoff parameters estimation process can be efficient, faster, and easily performed for several return period scenarios and for any regions.

\section{Conclusion}

This research article presented an efficient approach to accurate determination of potential runoff coefficient in Jeddah city using remote sensing and GIS. The effects of land use, soil hydrological characteristics, surface slope, were considered in calculating runoff coefficient and consequently runoff depth and runoff volume. The results of the research show that the total runoff volume for a rainfall depth of $106.3 \mathrm{~mm}$ is 136.5 million $\mathrm{m}^{3}$. Results also show that the main factors affect the total flood volumes, are the basin area, and the flow length. Additionally, it has been concluded that the higher $\mathrm{CN}$ value and slope percent, the higher runoff and flood hazards.

\section{References}

[1] Gheith, H. and Sultan, M. (2002) Construction of a Hydrologic Model for Estimating Wadi Runoff and Groundwater Recharge in the Eastern Desert, Egypt. Journal of Hydrology, 263, 36-55. https://doi.org/10.1016/S0022-1694(02)00027-6

[2] Mahmoud, S.H., Mohammad, F.S. and Alazba, A.A. (2013) A GIS-Based Approach for Determination of Potential Runoff Coefficient for Al-Baha Region, Saudi Arabia. 2013 International Conference on Sustainable Environment and Agriculture IPCBEE, 57, 97-102.

[3] Wanielista, M.P. and Yousef, Y.A. (1993) Stormwater Management. John Wiley \& Sons, Inc., New York.

[4] Dawod, G.M, Mirza, M.N. and Al-Ghamdi, K.A. (2012) GIS-Based Estimation of Flood Hazard Impacts on Road Network in Makkah City, Saudi Arabia. Environmental Earth Sciences, 67, 2205-2215. https://doi.org/10.1007/s12665-012-1660-9

[5] Sherwood, J.M. (1993) Estimation of Flood Volumes and Simulation of Flood Hydrographs for Ungagged Small Rural Streams in Ohio. Ohio Department of Transportation, Columbus.

[6] Ahmad, I., Verma, V. and Verma, M.K. (2015) Application of Curve Number Method for Estimation of Runoff Potential in GIS Environment. 2015 2nd International Conference on Geological and Civil Engineering IPCBEE, 80, 16-20.

[7] Xiao, B., Wang, Q.H., Fan, J., Han, F.P. and Dai, Q.H. (2011) Application of the SCS-CN Model to Runoff Estimation in a Small Watershed with High Spatial Heterogeneity. Pedosphere, 21, 738-749. https://doi.org/10.1016/S1002-0160(11)60177-X 
[8] Jasrotia, A. and Singh, R. (2006) Modeling Runoff and Soil Erosion in a Catchment Area, Using the GIS, in the Himalayan Region, India. Environmental Geology, 51, 9-37. https://doi.org/10.1007/s00254-006-0301-6

[9] Saleh, A. and Al-Hatrushi, S. (2009) Torrential Flood Hazards Assessment, Management, and Mitigation, in Wadi Aday, Muscat Area, Sultanate of Oman, a GIS and RS Approach. Egyptian Journal of Remote Sensing and Space Science, 12, 81-86.

[10] Chang, H., Franczyk, J. and Kim, C. (2009) What Is Responsible for Increasing Flood Risks? The case of Gangwon Province, Korea. Natural Hazards, 48, 339-354. https://doi.org/10.1007/s11069-008-9266-y

[11] Pandey, A. and Sahu, A.K. (2009) Generation of Curve Number Using Remote Sensing and Geographic Information System. Geospatial World.

https://www.geospatialworld.net/article/generationofcurvenumberusingremotesensi ngandgeographicinformationsystem/

[12] Zhao, D.Q., Chen, J.N., Wang, H.Z., Tong, Q.Y., Cao, S.B. and Sheng, Z. (2009) GIS-based Urban Rainfall-Runoff Modeling Using an Automatic Catchment-Discretization Approach: A Case Study in Macau. Environmental Earth Sciences, 59, 465-472. https://doi.org/10.1007/s12665-009-0045-1

[13] Chen, J., Hill, A. and Urbano, L. (2010) A GIS-Based Model for Urban Flood Inundation. Journal of Hydrology, 373, 184-192. https://doi.org/10.1016/j.jhydrol.2009.04.021

[14] Sumarauw, J.S.F. and Ohgushi, K. (2012) Analysis on Curve Number, Land Use and Land Cover Changes and the Impact to the Peak Flow in the Jobaru River Basin, Japan. International Journal of Civil \& Environmental Engineering, 12, 17-23. http://www.ijens.org/Vol_12_I_02/124102-3535-IJCEE-IJENS.pdf

[15] Nasiri, A. and Alipur, H. (2014) Determination the Curve Number Catchment by Using GIS and Remote Sensing. International Journal of Environmental, Chemical, Ecological, Geological and Geophysical Engineering, 8, 342-345.

[16] Bansode, A. and Patil, K.A. (2014) Estimation of Runoff by Using SCS Curve Number Method and ArcGIS. International Journal of Scientific \& Engineering Research, 5, 1213-1229.

[17] Viji, R., Prasanna, P.R. and Ilangovan, R. (2015) GIS Based SCS-CN Method for Estimating Runoff in Kundahpalam Watershed, Nilgries District, Tamilnadu. Earth Sciences Research Journal, 19, 59-64. https://doi.org/10.15446/esrj.v19n1.44714

[18] Gajbhiye, S. (2015) Estimation of Surface Runoff Using Remote Sensing and Geographical Information System. International Journal of $u$ - and e-Service, Science and Technology, 8, 113-122. https://doi.org/10.14257/ijunesst.2015.8.4.12

[19] Subyani, A.M. and Hajjar, A.F. (2016) Rainfall Analysis in the Contest of Climate Change for Jeddah Area, Western Saudi Arabia. Arabian Journal of Geosciences, 9, 122. https://doi.org/10.1007/s12517-015-2102-2

[20] Sharif, H.O., Al-Juaidi, F.H., Al-Othman, A., Al-Dousary, I., Fadda, E., Jamal-Uddeen, S. and Elhassan, A. (2016) Flood Hazards in an Urbanizing Watershed in Riyadh, Saudi Arabia. Geomatics, Natural Hazards and Risk, 7, 702-720. https://doi.org/10.1080/19475705.2014.945101

[21] Youssef, A., Pradhan, B. and Sefry, S. (2014) Remote Sensing-Based Studies Coupled with Field Data Reveal Urgent Solutions to Avert the Risk of Flash Floods in the Wadi Qus (East of Jeddah) Kingdom of Saudi Arabia. Natural Hazards, 75, 1465-1488. https://doi.org/10.1007/s11069-014-1383-1

[22] USDA (1986) Urban Hydrology for Small Watersheds. USDA, NRCS, CED, TR55. 
https://www.nrcs.usda.gov/Internet/FSE_DOCUMENTS/stelprdb1044171.pdf

[23] Subyani, A.M. and Al-Modayan, A.A. (2011) Flood Analysis in Western Saudi Arabia. Journal of King Abdulaziz University, 22, 17-36.

https://doi.org/10.4197/Ear.22-2.2 